O. V. Kylosova, A. B. Ilbuldina, O. V. Yaroslavtseva

Ural Federal University, 19 Mira street, 620002

Ekaterinburg

E-mail: o.v.yaroslavceva@urfu.ru

\title{
Study of instantaneous rate of corrosion of aluminum in media with different acidity
}

Instantaneous rate of aluminum corrosion in media with different acidity has been studied using a method of polarization and the electrical resistance. A resulting time series of instantaneous corrosion rate have been analyzed using the standardized range. As a result, it has been found that in all studied media corrosion process has a stochastic character, and time series of instantaneous rate are anti-persistent.

Key words: electrochemistry, corrosion, aluminum.

(c) Kylosova O. V., Ilbuldina A. B., Yaroslavtseva O. V., 2015

\section{Introduction}

From the viewpoint of observation of the development of corrosion process of greater interest is the differential characteristic of the rate of corrosion, socalled instantaneous rate of corrosion [1].

Since the corrosion process on the metal surface is likely to develop very unevenly, so fixing the instantaneous values of the corrosion rate one can be trace the alternation of its activation followed by temporary decay, which could again be replaced by reactivation. Observations of such changes in instantaneous rate at the initial stage of the corrosion process development can be used as the basis for the development of long-term corrosion forecast model. Therefore the choice of methodology of instantaneous corrosion rate research is actual.

\section{Experimental part}

As an object of the study aluminum wire ( $\mathrm{Al}$ not less than $99.6-99.7 \%$ (wt.)) has been used.

The instantaneous rate of corrosion of aluminum has been studied in three solutions: $\mathrm{H}_{2} \mathrm{SO}_{4}, \mathrm{Na}_{2} \mathrm{SO}_{4}$ and $\mathrm{NaOH}$, a pH of which was $0.78,5.71$ and 11.11 respectively. The instantaneous rate of corrosion has been evaluated by two methods: po- larization and electrical resistances. Measurement of polarization resistance and recording polarization curves have been performed in a standard electrochemical cell with divided cathode and anode spaces using Solartron 1280 C test station. A measurement design is shown in Fig. 1.

A program of measurement of the polarization resistance has included 
300 cycles, which consisted of measuring the currentless potential for 10 seconds, followed by potential sweep from -15 to $+15 \mathrm{mV}$ relative to the stationary potential, sweep rate is $3 \mathrm{mV} / \mathrm{s}$. Polarization curves for determining Tafel coefficients have been recorded by polarization from the cathode region to the anode one at linear potential sweep of $3 \mathrm{mV} / \mathrm{s}$.
Measurement of electrical resistance has been carried out by means of highresistance voltmeter. A measurement design is shown in Fig. 2. The time interval between measurements was 30 seconds, in each solution up to 300 measurements have been performed.

\section{Results and Discussion}

A typical curve of the time dependence of the experimental polarization resistance of the aluminum sample is shown in Fig. 3.

According to experimental data of the polarization resistance $\left(R_{p}\right)$ values of instantaneous corrosion rate in current units $\left(i_{\text {korr }}, \mathrm{A} / \mathrm{cm}^{2}\right)$ have been calculated by the Stern-Geary equation [2]:

$$
i_{\text {korr }}=\frac{b_{a} \cdot b_{k}}{2,3 \cdot\left(b_{a}+b_{k}\right) \cdot R_{p}},
$$

wherein $b_{a}$ and $b_{k}$ are the Tafel slopes of the anodic and cathodic processes.

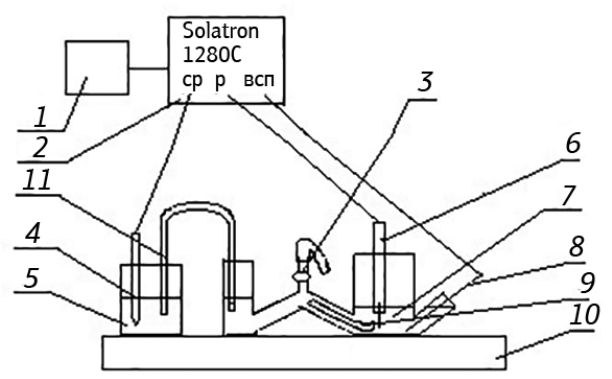

Fig. 1. Apparatus for polarization measurements: 1 - computer; 2 electrochemical station; 3-3-way stopcock;

4 - silver chloride reference electrode; 5 - saturated solution of $\mathrm{KCl} ; 6$ - working electrode; 7 - working solution; 8 - platinum auxiliary electrode; 9 - Haber-Luggin capillary; 10 - support for the cell; 11 - salt bridge
In all solutions under study oscillations have presented on the time dependence of the instantaneous corrosion rate. The presence of oscillations proves that the corrosion process has a stochastic character. The amplitude of oscillations and the general trend of change of polarization resistance suggest the following features of the corrosion process:

- in a neutral salt solution dissolving aluminum occurs in pores existing on the surface of the oxide film;

- in sulfuric acid solution the initial more or less active dissolution is replaced by the reduction of the oxide film, and the dissolution process slows down and localizes in pores of the oxide film;

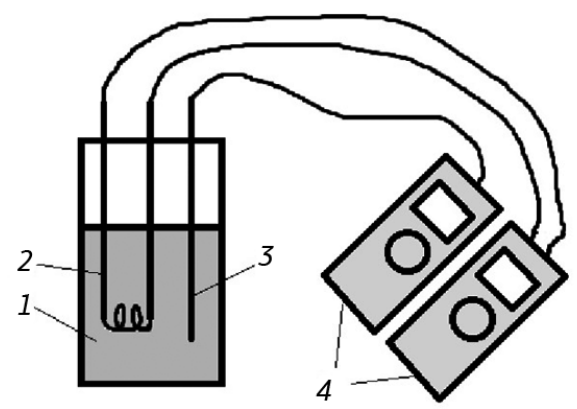

Fig. 2. The electric resistance measuring circuit 1 - glass with the test solution, 2 - sample (in the form of wire spiral), 3 thermocouple, 4 - high-resistance voltmeters 
- in alkali medium dissolution of aluminum observed in cracks of fast-growing aluminate film.

Experimental curves of the change in time of the aluminum sample electrical resistance also had characteristic oscillations in all studied media (Fig. 4).

The instantaneous rate of corrosion $(V, \mu \mathrm{m} / \mathrm{s})$ can be calculated from the dependence of the electrical resistance on the radius of the wire sample [3]:

$$
V=-\frac{\partial r}{\partial t}=\left(\frac{\rho \cdot l}{4 \pi}\right)^{1 / 2} \cdot R(t)^{-3 / 2} \cdot \frac{\partial R}{\partial t}
$$

wherein $r$ is the radius of aluminum wire; $\rho$ is the electrical resistivity of aluminum; $l$ is the length of aluminum wire; $R(t)$ is the resistance value at time $t$.

The resulting time dependencies of the corrosion rate have oscillations regardless of the composition of the corrosive solution. This indicates that despite the significantly different values of the electric resistance and oscillation amplitude in

\section{Conclusion}

1. Studies of electrochemical behavior of aluminum by electrical and polarization resistance in solutions with different $\mathrm{pH}$ have been carried out.

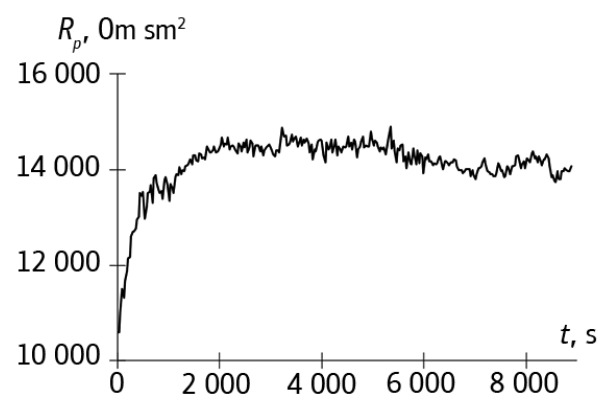

Fig. 3. The polarization resistance of the aluminum sample in sodium sulfate solution different solutions the stochastic character of dissolution maintains.

In order to identify the character (random or fractal) the time series have been processed by the method of Hurst. The method involves the standardization of data to zero, mean and standard deviation. The calculated values of the Hurst exponent for the time series of polarization and electrical resistances in the studied media (Table 1 ) are in the range from 0 to 0.5 . Accordingly, all of the analyzed experimental time series are anti-persistent, so observed at the initial time moment the growth of corrosion rate subsequently may give place to a decrease.

Table 1

The Hurst exponent for the time series of polarization and electrical resistance

\begin{tabular}{l|c|c|c}
\multirow{2}{*}{ Time series } & \multicolumn{3}{|c}{ Solution } \\
\cline { 2 - 4 } & $\mathrm{H}_{2} \mathrm{SO}_{4}$ & $\mathrm{Na}_{2} \mathrm{SO}_{4}$ & $\mathrm{NaOH}$ \\
\hline $\begin{array}{l}\text { Polarization } \\
\text { resistance }\end{array}$ & $0.42 \pm 0.21$ & $0.27 \pm 0.13$ & $0.27 \pm 0.08$ \\
\hline $\begin{array}{l}\text { Electrical } \\
\text { resistance }\end{array}$ & $0.29 \pm 0.02$ & $0.29 \pm 0.05$ & $0.33 \pm 0.04$
\end{tabular}

2. On the basis of the obtained time dependencies of the instantaneous corrosion rate it was confirmed that the process of corrosion on the surface of

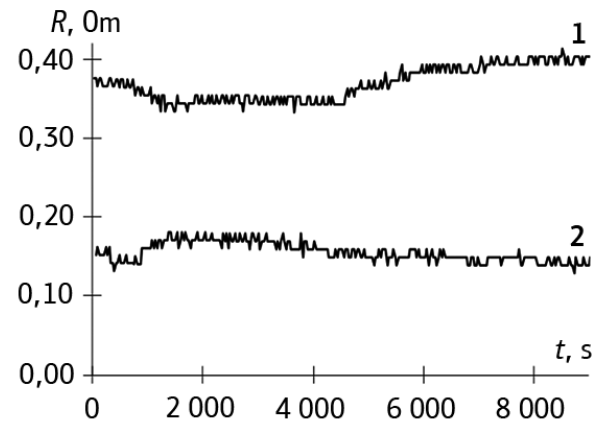

Fig. 4. The electric resistance of the aluminum sample:

1 - in sulfuric acid; 2 - in alkali medium 
the aluminum sample develops nonmonotonically: oscillations presented on graphs suggest the stochastic character of the process.

3. When processing time series of polarization and electrical resistance it was revealed that the corrosion process on the aluminum surface has anti-persistent character regardless of the presence of the passive film.

The results of the measurement of the polarization resistance data have confirmed known data on aluminum corrosion resistance in media with different $\mathrm{pH}$, more specifically:
- destruction of the passive film and intensive dissolution in alkaline solution;

- passivation of the oxide film in a neutral solution;

- reduction by the present in the solution oxygen of the oxide film dissolving upon contact with an acidic solution.

5. The analysis of experimental data has revealed that the corrosion rate determination by the electric resistance is possible in case of active dissolution of the metal in a corrosive medium, for example aluminum in an alkaline medium. In the presence of the growing passive film this method is not applicable.

1. Gerasimov V. V. Corrosion of aluminum and its alloys. M., Metallurgiya, 1988. 113 pp.

2. Zhuk N.P. A Course of the Theory of Corrosion and Protection of Metals. M., Metallurgiya, 1976. $472 \mathrm{pp}$.

3. Peters E. Fractal analysis of financial markets: the application of chaos theory to investment and economics. M., Internet Trading, 2004. 304 pp. 
О. В. Кылосова, А. Б. Илбулдина, О. В. Ярославцева

Уральский федеральный университет 620002, Екатеринбург, ул. Мира, 28. E-mail: o.v.yaroslavceva@urfu.ru

\section{Исследование мгновенной скорости алюминия в средах с разной кислотностью}

Методом поляризационного и электрического сопротивления исследована мгновенная скорость коррозии алюминия в средах с различной кислотностью. Полученные временные ряды мгновенной скорости коррозии проанализированы методом нормированного размаха. В результате установлено, что во всех исследованных средах процесс коррозии имеет стохастический характер, причем временные ряды мгновенной скорости антиперсистентны.

Ключевые слова: электрохимия, коррозия, алюминий.

() Кылосова О. В., Илбулдина А. Б., Ярославцева О. В., 2015

\section{Введение}

С точки зрения наблюдения

следующим временным затуханием, за развитием коррозионного процесса, больший интерес представляет дифференциальная характеристика скорости коррозии, так называемая мгновенная скорость коррозии [1].

Поскольку коррозионный процесс на металлической поверхности, скорее всего, развивается крайне неравномерно, то фиксируя мгновенные значения скорости коррозии, можно проследить чередование его активации с покоторое вновь может сменяться реактивацией. Наблюдения за подобными изменением мгновенной скорости на начальном этапе развития коррозионного процесса могут быть положено в основу при разработке долгосрочной прогнозной модели коррозии. Поэтому актуальным является выбор методологии исследования мгновенной скорости коррозии.

\section{Экспериментальная часть}

В качестве объекта исследования использовали алюминиевую проволоку (Al не менее 99,6-99,7 \%(масс.)).

Мгновенную скорость коррозии алюминия изучали в трех растворах: $\mathrm{H} 2 \mathrm{SO}_{4}, \mathrm{Na}_{2} \mathrm{SO}_{4}$ и $\mathrm{NaOH}, \mathrm{pH}$ которых составляла $0,78,5,71$ и 11,11 соответ- 
ственно. Мгновенную скорость коррозии оценивали двумя методами: поляризационного и электрического сопротивлений. Измерение поляризационного сопротивления и снятие поляризационных кривых осуществляли в стандартной электрохимической ячейке с разделенными катодным и анодным пространствами при помощи измерительной станции Solartron 1280С. Схема измерения представлена на рис. 1.

Программа измерения поляризационного сопротивления включала 300 циклов, которые состояли из измерения бестокового потенциала в течение 10 c, с последующей разверткой потенциала от -15 до + 15 мВ относительно стационарного потенциала, скорость развертки $3 \mathrm{mB} / \mathrm{c}$. Поляризационные кривые для определения коэффициентов Тафеля снимали поляризацией из катодной области в анодную при линейной развертке потенциала $3 \mathrm{mB} / \mathrm{c}$.

Измерение электрического сопротивления осуществляли при помощи высокоомного вольтметра. Схема установки приведена на рис. 2. Временной интервал между измерениями составлял 30 с, в каждом растворе осуществляли по 300 измерений.

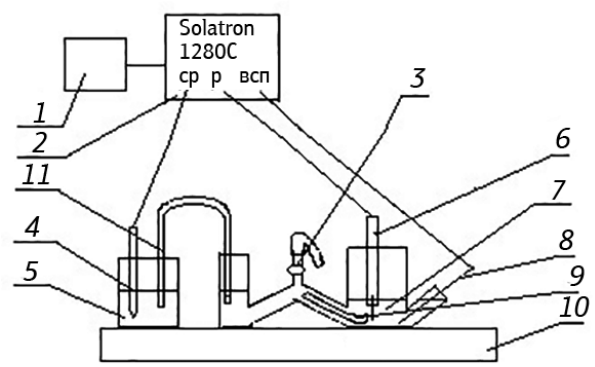

Рис. 1. Схема установки для поляризационных измерений:

1 - компьютер; 2 - электрохимическая станция; 3-3-ходовой краник; 4 - хлоридсеребряный электрод сравнения; 5 - насыщенный раствор $\mathrm{KCl}$; 6 - рабочий электрод; 7 - рабочий раствор; 8 - платиновый вспомогательный электрод; 9 - капилляр Гебера - Луггина;

10 - подставка под ячейку; 11 - электролитический ключ

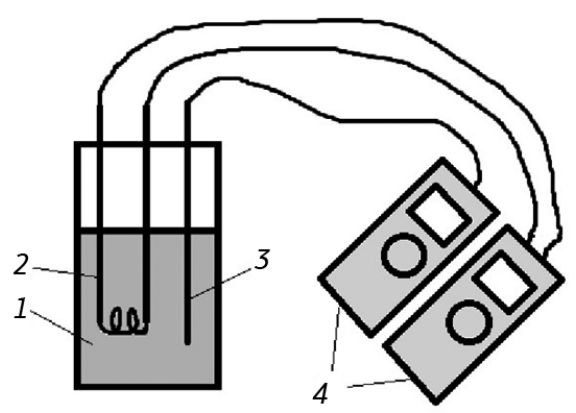

Рис. 2. Схема измерения электрического сопротивления: 1 - стакан с исследуемым раствором, 2 - исследуемый образец (в виде спирали из проволоки), 3 термопара, 4 - высокоомные вольтметры

\section{Результаты и их обсуждение}

Типичная кривая временной зависимости экспериментального поляризационного сопротивления алюминиевого образца приведена на рис. 3.

По экспериментальным данным поляризационного сопротивления $\left(R_{p}\right)$ были рассчитаны значения мгновенной скорости коррозии в токовых единицах $\left(i_{k o r r}, \mathrm{~A} / \mathrm{cm}^{2}\right)$ по уравнению Штерна Гири [2]:

$$
i_{\text {korr }}=\frac{b_{a} \cdot b_{k}}{2,3 \cdot\left(b_{a}+b_{k}\right) \cdot R_{p}},
$$


где $b_{a}$ и $b_{k}$ - тафелевские наклоны анодного и катодного процессов.

Во всех исследуемых растворах на временной зависимости мгновенной скорости коррозии присутствовали колебания. Наличие колебаний свидетельствует о том, что коррозионный процесс имеет стохастический характер. Амплитуда колебаний и общий тренд изменения поляризационного сопротивления позволяют предположить следующие особенности коррозионного процесса:

- в нейтральном растворе соли растворение алюминия происходит в поpax имеющейся на поверхности оксидной пленки;

- в растворе серной кислоты первоначальное более или менее активное растворение сменяется восстановлением оксидной пленки, и процесс растворения замедляется и локализуется в порах оксидной пленки;

- в щелочи наблюдается растворение алюминия в трещинах быстрорастущей пленки алюмината.

Экспериментальные кривые изменения во времени электрического сопротивления алюминиевого образца также имели характерные колебания во всех исследованных средах (рис. 4).

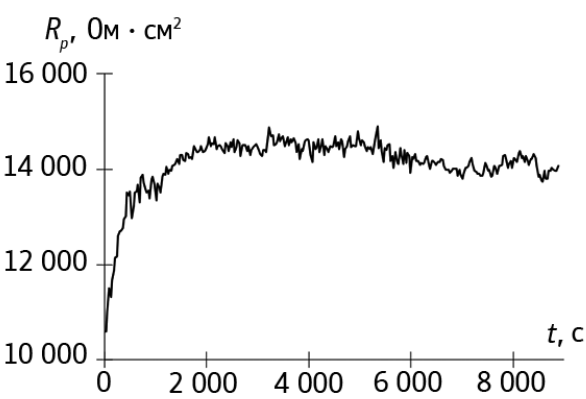

Рис. 3. Поляризационное сопротивление алюминиевого образца в растворе сульфата натрия
Мгновенная скорость коррозии ( $V$, мкм/с) может быть рассчитана исходя из зависимости электрического сопротивления от радиуса проволочного образца [3]:

$$
V=-\frac{\partial r}{\partial t}=\left(\frac{\rho \cdot l}{4 \pi}\right)^{1 / 2} \cdot R(t)^{-3 / 2} \cdot \frac{\partial R}{\partial t},
$$

где $r$ - радиус алюминиевой проволоки; $\rho$ - удельное электрическое сопротивление алюминия; $l$ - длина алюминиевой проволоки; $R(t)$ - значение сопротивления в момент времени $t$.

Полученные временные зависимости скорости коррозии имеют колебания вне зависимости от состава коррозионного раствора. Это свидетельствует о том, что, несмотря на значительно отличающиеся значения электрического сопротивления и амплитуды колебаний, в разных раствоpax стохастический характер растворения сохраняется.

С целью выявления характера (случайный или фрактальный) временные ряды были обработаны по методике Херста. Метод предполагает нормирование данных к нулевому, среднему и стандартному отклонению. Рассчитанные значения показателя Херста для временных рядов поляризацион-

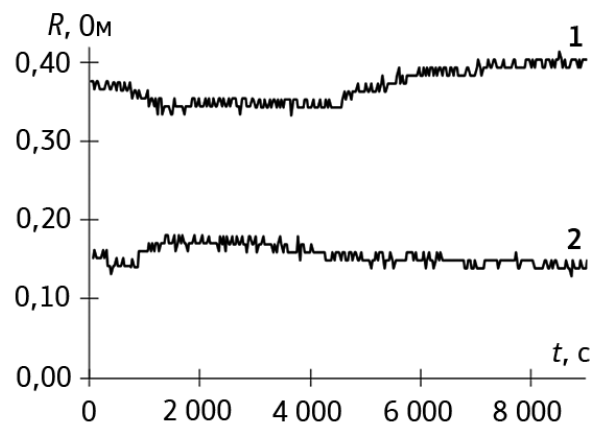

Рис. 4. Электрическое сопротивление алюминиевого образца: 1 - в серной кислоте; 2 - в щелочи 
ного и электрического сопротивлений в исследуемых средах (табл. 1) лежат в интервале от 0 до 0,5. Соответственно, все проанализированные экспериментальные временные ряды антиперсистентны, то есть наблюдаемый в начальный момент времени рост скорости коррозии в дальнейшем может смениться уменьшением.
Таблица 1

Показатель Херста временных рядов поляризационного и электрического сопротивления

\begin{tabular}{l|c|c|c}
\multirow{2}{*}{$\begin{array}{l}\text { Временной } \\
\text { ряд }\end{array}$} & \multicolumn{3}{|c}{ Solution } \\
\cline { 2 - 4 } & $\mathrm{H}_{2} \mathrm{SO}_{4}$ & $\mathrm{Na}_{2} \mathrm{SO}_{4}$ & $\mathrm{NaOH}$ \\
\hline $\begin{array}{l}\text { Поляризаци- } \\
\text { онное сопро- } \\
\text { тивление }\end{array}$ & $0,42 \pm 0,21$ & $0,27 \pm 0,13$ & $0,27 \pm 0,08$ \\
\hline $\begin{array}{l}\text { Электриче- } \\
\text { ское сопро- } \\
\text { тивление }\end{array}$ & $0,29 \pm 0,02$ & $0,29 \pm 0,05$ & $0,33 \pm 0,04$ \\
\end{tabular}

\section{Выводы}

1. Проведены исследования электрохимического поведения алюминия методами электрического и поляризационного сопротивления в растворах с разным $\mathrm{pH}$.

2. На основании полученных временных зависимостей мгновенной скорости коррозии подтверждено, что процесс коррозии на поверхности алюминиевого образца развивается немонотонно: имеющиеся на графиках колебания свидетельствуют о стохастическом характере процесса.

3. При обработке временных рядов поляризационного и электрического сопротивлений выявлено, что коррозионный процесс на поверхности алюминия имеет антиперсистентный характер вне зависимости от наличия пассивной пленки.

Результатами измерения поляризационного сопротивления подтвержде- ны известные данные о коррозионной стойкости алюминия в средах с различным рН, а именно:

- разрушение пассивной пленки и интенсивное растворение в щелочном растворе;

- пассивация оксидной пленкой в нейтральном растворе;

- восстановление присутствующим в растворе кислородом, оксидной пленки, растворяющейся при контакте с кислым раствором.

5. В ходе анализа экспериментальных данных установлено, что определение скорости коррозии методом электрического сопротивления возможно в случае активного растворения металла в коррозионной среде, как например алюминий в щелочной среде. При наличии растущей пассивной пленкой этот метод не применим.

1. Герасимов В. В. Коррозия алюминия и его сплавов. М. : Металлургия, 1988. 113 с. 2. Жук Н. Р. Курс теории коррозии и защиты металлов. М. : Металлургия, 1976. $472 \mathrm{c}$.

3. Петерс Э. Фрактальный анализ финансовых рынков: применение теории хаоса в экономике / пер. с англ. М.: Интернет-Трейдинг, 2004. 304 с. 